\title{
Nitrogen cycling in sediments with different organic loading
}

\author{
Niels P. Sloth ${ }^{1}$, Henry Blackburn ${ }^{2}$, Lars Stenvang Hansen ${ }^{2}$, Nils Risgaard-Petersen ${ }^{2}$, \\ Bente Aa. Lomstein ${ }^{2, *}$
}

${ }^{1}$ County of Northern Jutland, Department of the Environment, Amtsgaarden, Niels Bohrsvej 30, Post Box 8300, DK-9220 Aalborg Øst, Denmark

${ }^{2}$ Department of Microbial Ecology, Institute of Biological Sciences, University of Aarhus, Ny Munkegade, Bldg 540, DK-8000 Århus C, Denmark

\begin{abstract}
Sediment cores from an intertidal marine area were experimentally loaded with different amounts of organic material, in order to investigate regulation of the processes in the nitrogen cycle, and the fate of the inorganic and organic $\mathrm{N}\left(\mathrm{NH}_{4}{ }^{+}, \mathrm{NO}_{3}{ }^{-}, \mathrm{DON}\right.$, and urea) released through mineralization. The particulate organic material was added in amounts of $30 \mathrm{~g} \mathrm{dw} \mathrm{m}^{-2}$ (30MIX) and $100 \mathrm{~g} \mathrm{dw} \mathrm{m}^{-2}$ (100MIX) mixed into the sediment, and as $100 \mathrm{~g} \mathrm{dw} \mathrm{m}^{-2}$ (100SURF) to the sediment top layer. Processes and pools were related to unamended controls (CTRL). The cores were incubated with low ( 0 to $2 \mu \mathrm{M})$ $\mathrm{NO}_{3}{ }^{-}$in the overlying water, and measurements were made after $1 \mathrm{wk}$. Total sediment respiration rate measured as $\mathrm{O}_{2}$ uptake and $\mathrm{CO}_{2}$ release were 10 and $18 \mathrm{mmol} \mathrm{m}^{-2} \mathrm{~d}^{-1}$, respectively, in the CTRL, gradually increasing in the order of treatments (30MIX, 100MIX, 100SURF) to 62 and $64 \mathrm{mmol} \mathrm{m}^{-2} \mathrm{~d}^{-1}$ respectively in 100SURF. Higher loading resulted in increasing effluxes of $\mathrm{NH}_{4}{ }^{+}$. DON effluxes were quantitatively significant only from the 100SURF sediment cores. There was an accumulation of dissolved $\mathrm{N}$-species in the sediment amounting to 12 to $28 \%$ of the loading, with most increase where the organic matter was mixed into the sediment. Nitrification and denitrification rates were highest in the moderately loaded sediment (30MIX), followed by control cores and the 100MIX. There was no nitrification or denitrification activity in the 100SURF cores, and $\mathrm{NO}_{3}{ }^{-}$was completely absent in this sediment. Dissimilative $\mathrm{NO}_{3}{ }^{-}$reduction to $\mathrm{NH}_{4}{ }^{+}$was insignificant in all treatments. The experiment showed that moderate loading increased $\mathrm{N}$ removal through denitrification, while high loading decreased denitrification. The marked differences in the fate of nitrogen, due to organic matter distribution, demonstrated the importance of bioturbation and other physical mixing processes.
\end{abstract}

KEY WORDS: Sediment · Nitrification · Denitrification · Dissolved organic nitrogen · Organic loading

\section{INTRODUCTION}

Sediments play a significant role in the transformations of nitrogen compounds in coastal systems (Fenchel \& Blackburn 1979). The mechanisms involved in the mineralization processes have been extensively studied: N-mineralization (e.g. Blackburn 1979), nitrification (Henriksen \& Kemp 1988), denitrification (Seitzinger 1990), and dissolved organic nitrogen (DON) and urea cycling (e.g. Lomstein \& Blackburn 1992). A quite complete understanding of the regulation of these microbial processes in natural systems has

\footnotetext{
-Addressee for correspondence
}

to some extent been achieved, and effects of anthropogenic and natural perturbations can be predicted by computer modelling (Blackburn \& Blackburn 1992). Among the basic differences between sediments from different ecosystems is the amount of organic loading they receive, due to sedimentation from the water column or internally produced organics derived from flora and/or fauna. A number of questions remain unresolved, such as: To what degree is nitrogen recycled into new primary production, and how much is removed by denitrification or burial? What are the mechanisms involved in the transformations, and would it be possible to model scenarios from knowledge of these mechanisms? 
Increased organic loading increases sediment $\mathrm{O}_{2}$ consumption and N-mineralization (Kelly \& Nixon 1984, Kemp \& Boynton 1984, Kelly et al. 1985). Early models predicted that denitrification would decrease with organic loading (Blackburn 1990). Caffrey et al. (1993) experimentally loaded sediment with yeast cells to investigate some of these questions. In the present experiment we used newly developed isotopic methods and more exact measurements to examine nitrification, denitrification and DON-cycling in organically loaded sediments. In contrast to Caffrey et al. (1993), the $\mathrm{NO}_{3}{ }^{-}$concentration in the overlying water was low $(0$ to $2 \mu \mathrm{M})$. The results were integrated and related to $\mathrm{C}$-mineralization. The loading rates chosen in the experiment were 0 to $100 \mathrm{~g}$ dry weight $(\mathrm{dw}) \mathrm{m}^{-2}$, thus simulating a loading of 0 to $20 \%$ of the primary production in the coastal areas in Denmark (500 to $750 \mathrm{~g}$ $\left.\mathrm{dw} \mathrm{m}^{-2} \mathrm{yr}^{-1}\right)$.

\section{METHODS}

Sampling and experimental setup. Sandy sediment was sampled from the intertidal zone in Limfjorden, Denmark, south of the Aggersund Bridge. The sediment was sieved at the site ( $1 \mathrm{~mm}$ screen) to remove macrofauna. In the laboratory, baker's yeast was added to the sediment in 4 different treatments: Control sediment with no addition (CTRL), $30 \mathrm{~g} \mathrm{dw} \mathrm{m}^{-2}$ mixed into the sediment (30MIX), $100 \mathrm{~g}$ dry weight $\mathrm{m}^{-2}$ mixed into the sediment (100MIX), and $100 \mathrm{~g} \mathrm{dw}$ $\mathrm{m}^{-2}$ added to a $0.5 \mathrm{~cm}$ layer below a top $0.5 \mathrm{~cm}$ layer with no addition (100SURF). The primary production in the coastal areas of Denmark is on average 200 to $300 \mathrm{~g} \mathrm{C} \mathrm{m}^{-2} \mathrm{yr}^{-1}$, with a C-content of $40 \%$ in the total dry weight this would be 500 to $750 \mathrm{~g} \mathrm{dw} \mathrm{m}^{-2} \mathrm{yr}^{-1}$. The organic loading in the $30 \mathrm{MIX}$ treatment equals 4 to $6 \%$ of the annual production, thus simulating a large sedimentation, comparable to sedimentation of a spring bloom in the Danish coastal areas (Lomstein \& Blackburn 1992). The yeast had a $C: N$ ratio of 7.5 (Caffrey et al. 1993). Four cores of i.d. $5.2 \mathrm{~cm}$ and 4 cores of i.d. $3.6 \mathrm{~cm}$ from each treatment were set up with a sediment height of $17 \mathrm{~cm}$ and an overlying water phase of $6 \mathrm{~cm}$. The water phase in the large cores was mixed with magnetic stirrers $(3 \mathrm{~cm})$ driven by a rotating external magnet and was connected to a continuous flow system, renewing the water phases with continuously aerated, 24\% artificial sea water (ASW) (Strickland \& Parsons 1965). The flow rate was $0.5 \mathrm{ml} \mathrm{min}^{-1}$ in CTRL and 30MIX and 1.5 to $1.7 \mathrm{ml} \mathrm{min}^{-1}$ in $100 \mathrm{MIX}$ and 100SURF. The small cores (i.d. $3.6 \mathrm{~cm}$ ) were placed in an aerated reservoir with continuous exchange of $24 \%$ ASW. The temperature was $15^{\circ} \mathrm{C}$. The flow was run for $1 \mathrm{wk}$ before measurements of rates, since ear- lier experiments (Caffrey et al. 1993) indicated that after this time flux rates would be reasonably constant. The cores were kept in the dark throughout the experiment, to exclude activity from microphytobenthos.

Flux measurements. Samples for analysis of $\mathrm{NH}_{4}{ }^{+}$, $\mathrm{NO}_{3}{ }^{-}, \mathrm{DON}$, and urea were taken in polyethylene vials from the reservoir and at the outflow from the individual cores, and were frozen. DON samples were filtered $\left(0.2 \mu \mathrm{m}\right.$, Sartorius). Analyses of $\mathrm{NH}_{4}{ }^{+}, \mathrm{NO}_{3}{ }^{-}$ and urea were done within 1 mo on a Technicon autoanalyzer by standard methods (Bower \& Holm-Hansen 1980, Grashoff et al. 1983, Price \& Harrison 1987) and DON was analyzed by the chemiluminescence method described by Walsh (1989) on an Antek 7000 analyzer. Samples for $\mathrm{O}_{2}$ and $\mathrm{CO}_{2}$ were taken in gas-tight vials (Labco Exetainers). The outflow tubes from the individual cores had low permeability to gas diffusion (Isoversinic, Verneret, France). Concentrations of $\mathrm{O}_{2}$ in the inflow reservoir and in the outflow samples were measured immediately after sampling with an $\mathrm{O}_{2}$ electrode (Revsbech 1989), continuously calibrated in water at the same temperature and salinity as the samples. Concentrations of total $\mathrm{CO}_{2}$ in the outflow samples and in the inflow reservoir were measured by Gran titrations (Grashoff et al. 1983). Flux rates were calculated using the formula: $F=\mathrm{d} C \times \mathrm{FR} / \mathrm{SA}$, where $\mathrm{d} C$ is concentration difference between in- and outflow, FR is flow rate, and SA is surface area of sediment core.

Rate measurements of nitrogen transformations. After the flux measurements of $\mathrm{NH}_{4}{ }^{+}, \mathrm{NO}_{3}{ }^{-}, \mathrm{DON}$ and urea were terminated, ${ }^{15} \mathrm{NO}_{3}{ }^{-}$was added to the reservoir water to a concentration of $50 \mu \mathrm{M}$ for measurements of nitrification and denitrification. After $36 \mathrm{~h}$, to achieve steady state in outflow concentrations of ${ }^{15} \mathrm{~N}$ species, 3 samples were taken from the reservoir, and from the outflow of each core during a $6 \mathrm{~h}$ period. Samples for ${ }^{15} \mathrm{NO}_{3}{ }^{-}$and ${ }^{15} \mathrm{NH}_{4}{ }^{+}$analysis were taken in polyethylene vials and frozen; samples for $\mathrm{N}_{2}$ isotopic composition were taken in gas-tight vials (Labco Exetainers) and preserved with $1 \%$ (w/v) $\mathrm{ZnCl}_{2}$. Atom $\%$ of ${ }^{15} \mathrm{~N}$ in $\mathrm{NO}_{3}{ }^{-}$was analyzed by bacterial reduction followed by mass spectrometry (RisgaardPetersen et al. 1993), and in $\mathrm{NH}_{4}{ }^{+}$by a combined microdiffusion hypobromite oxidation as described by N. Risgaard-Petersen, S. Rysgaard \& N. P. Revsbech (unpubl.). Denitrification was calculated from the ratios of ${ }^{15} \mathrm{~N}^{15} \mathrm{~N}:{ }^{14} \mathrm{~N}^{15} \mathrm{~N}$ (Nielsen 1992). Nitrate released to the water from nitrification in the sediment was calculated from the concentration change and the isotopic dilution of the ${ }^{15} \mathrm{NO}_{3}{ }^{-}$(Nishio et al. 1983). After the isotopic measurements, the reservoir water was changed to ASW with no added $\mathrm{NO}_{3}{ }^{-}$, and a saturated $\mathrm{C}_{2} \mathrm{H}_{2}$ solution was added regularly to the water phase in 2 cores from each treatment to give a concentration 


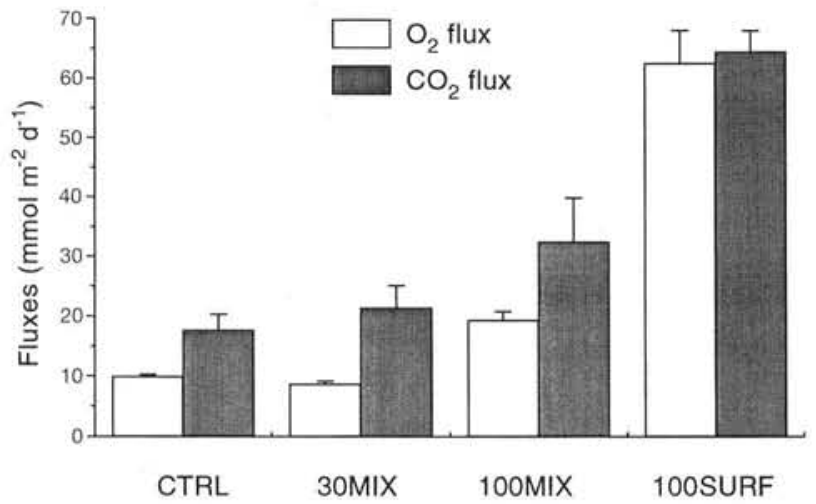

Fig. 1. $\mathrm{O}_{2}$ consumption and $\mathrm{CO}_{2}$ efflux measured in the different treatments. Averages of 4 cores shown; error bars show SE

of $1 \%(\mathrm{v} / \mathrm{v})$ to inhibit nitrification. Samples from the reservoir and the outflow were taken after $24 \mathrm{~h}$ when a new steady state in $\mathrm{NH}_{4}{ }^{+}$and $\mathrm{NO}_{3}{ }^{-}$fluxes was achieved after inhibition of nitrification (Sloth et al. unpubl.). Rates of nitrification were calculated from the differences in fluxes of $\mathrm{NH}_{4}{ }^{+}$before and after inhibition (Sloth et al. 1992).

$\mathrm{O}_{2}$ and nutrient profiles. Concentration profiles of $\mathrm{O}_{2}$ were measured with $\mathrm{O}_{2}$-microelectrodes (Revsbech 1989) in 2 cores from each treatment after the rate measurements were completed. Porewater nutrient profiles $\left(\mathrm{NH}_{4}{ }^{+}, \mathrm{NO}_{3}{ }^{-}\right.$, urea, and DON) were measured in four $36 \mathrm{~mm}$ i.d. cores for each treatment. The sediment was sectioned into $2 \mathrm{~mm}$ slices from 0 to $8 \mathrm{~mm}$ depth, $4 \mathrm{~mm}$ slices from 8 to $24 \mathrm{~mm}$ and $8 \mathrm{~mm}$ slices from 24 to $56 \mathrm{~mm}$. Porewater was obtained by centri- fugation (3000 rpm, $2000 \times g$, for $10 \mathrm{~min})$, and samples from the same depth and treatment were pooled and frozen for later analysis. Porewater samples for DON analysis were pooled in some adjacent depths to get enough sample for analysis. Adsorbed $\mathrm{NH}_{4}{ }^{+}$was extracted with $2 \mathrm{M} \mathrm{KCl}$ (Blackburn 1979).

\section{RESULTS}

\section{$\mathrm{O}_{2}$ and $\mathrm{CO}_{2}$ fluxes}

Oxygen uptake and $\mathrm{CO}_{2}$ effluxes showed no significant differences between the CTRL and 30MIX treatments, some increase in 100MIX, and a marked increase in 100SURF (Fig. 1). Oxygen uptake and $\mathrm{CO}_{2}$ effluxes showed the same general pattern, but $\mathrm{CO}_{2}$ effluxes were higher than $\mathrm{O}_{2}$ uptake, except in the 100SURF treatment, where $\mathrm{O}_{2}$ and $\mathrm{CO}_{2}$ exchange rates were almost equal.

\section{$\mathrm{N}$ fluxes}

Fluxes of $\mathrm{N}$-species (Fig. 2) were dominated by $\mathrm{NO}_{3}^{-}$ efflux at the low loading treatments (CTRL and 30MIX), and by $\mathrm{NH}_{4}{ }^{+}$efflux at the high loadings. The highest $\mathrm{NO}_{3}{ }^{-}$efflux was from 30MIX, followed by CTRL and 100MIX. There was no $\mathrm{NO}_{3}{ }^{-}$efflux from the100SURF sediment. The difference in $\mathrm{NO}_{3}{ }^{-}$efflux among treatments indicated different nitrification rates. $\mathrm{NH}_{4}{ }^{+}$effluxes increased with increased loading
Fig. 2. Fluxes of $\mathrm{N}$-species: $\mathrm{NO}_{3}^{-}, \mathrm{NH}_{4}{ }^{+}, \mathrm{DON}$, and urea. Averages of 4 cores shown; SE indicated by error bars
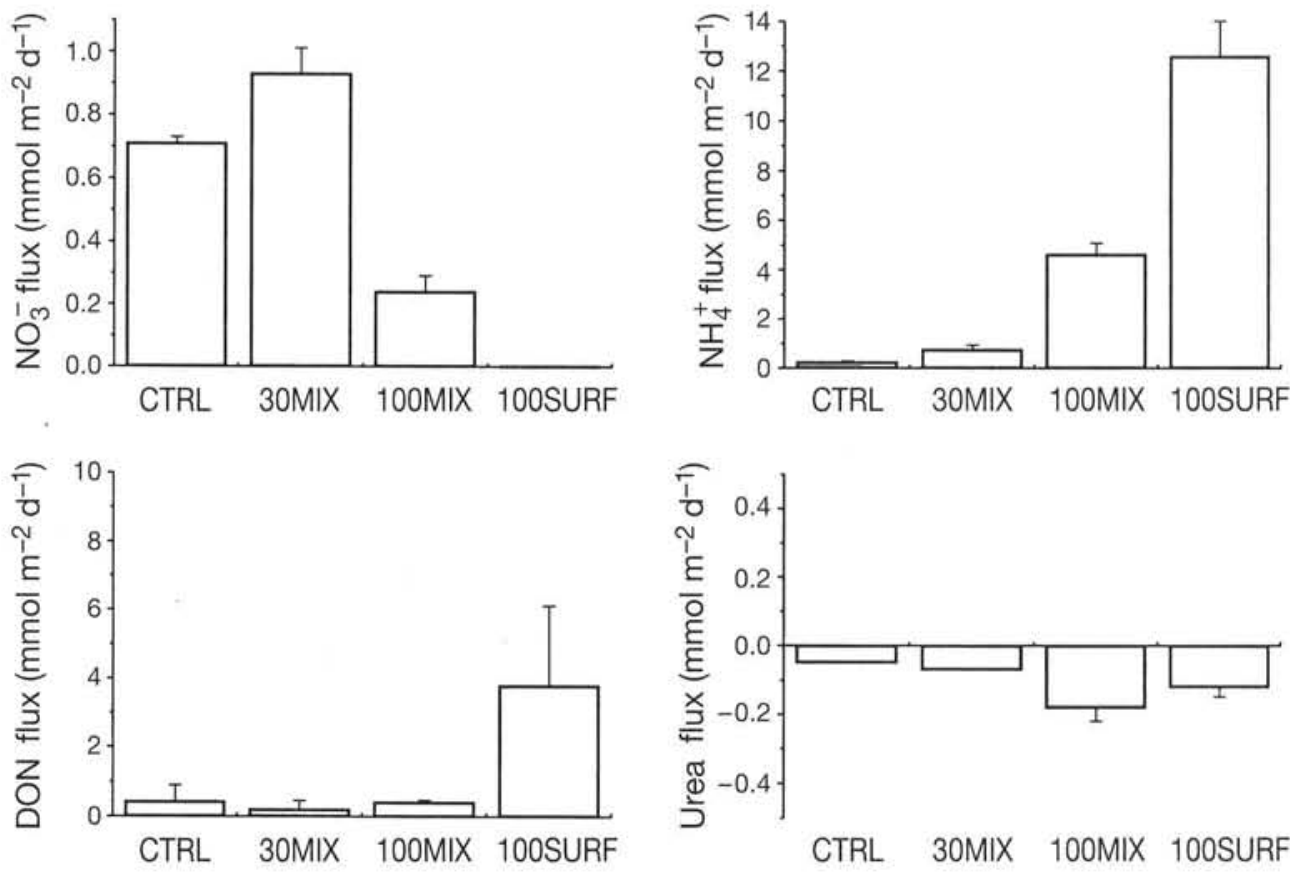

CTRL 30MIX 100MIX 100SURF 
rate (Fig. 2). Further, the $\mathrm{NH}_{4}{ }^{+}$flux increased when the organic material was added to the surface $(12.6 \mathrm{mmol}$ $\mathrm{m}^{-2} \mathrm{~d}^{-1}$ in 100SURF) compared to when the organic material was mixed into the sediment $\left(4.6 \mathrm{mmol} \mathrm{m}^{-2}\right.$ $\mathrm{d}^{-1}$ in 100MIX). DON effluxes were lower than $0.5 \mathrm{mmol} \mathrm{m}^{-2} \mathrm{~d}^{-1}$ in all treatments, except in the 100SURF with rates of $3.8 \mathrm{mmol} \mathrm{m}^{-2} \mathrm{~d}^{-1}$. Urea fluxes were generally directed into the sediment. This was due to some urea $(0.38 \mu \mathrm{M})$ in the inflow water, but in all cases fluxes were lower than $0.2 \mathrm{mmol} \mathrm{m}^{-2} \mathrm{~d}^{-1}$.

\section{Profiles}

There was a marked difference in concentration profiles of DON, $\mathrm{NH}_{4}{ }^{+}$and urea between treatments (Fig. 3). DON concentrations were relatively constant in the deeper parts (below $10 \mathrm{~mm}$ ) of the sediment in the CTRL and mixed treatments. The concentration in the deeper layers was the same for CTRL and 30MIX (average of $57 \mu \mathrm{M}$ ), and higher for the 100MIX (average of $153 \mu \mathrm{M})$. In the CTRL and mixed treatments the DON concentrations were lower in the upper $10 \mathrm{~mm}$ of the sediment than in deeper parts. The 100SURF had a peak $(\sim 325 \mu \mathrm{M})$ in the top $10 \mathrm{~mm}$, where the yeast cells were placed, and concentrations decreasing to CTRL levels in the deeper sediment. In contrast to DON, $\mathrm{NH}_{4}{ }^{+}$porewater concentrations increased with sediment depth in the CTRL and mixed treatments; this indicated production in all sediment strata, and accumulation in the deeper parts; concentrations increased with the amount of loading in the order CTRL, 30MIX, and 100MIX. The 100SURF had a peak $(\sim 1500 \mu \mathrm{M})$ in the 0 to $15 \mathrm{~mm}$ surface layer. Urea had surface peaks in all treatments, indicating either that degradation was inhibited, or that production was stimulated at higher redox potentials. The highest surface concentrations were seen in the CTRL and 30MIX cores.

The $\mathrm{NO}_{3}^{-}$concentration profiles (Fig. 4) showed peaks in the upper 5 to $10 \mathrm{~mm}$ in CTRL and mixed treatments. Consistent with the $\mathrm{NO}_{3}{ }^{-}$efflux data, no $\mathrm{NO}_{3}{ }^{-}$was seen in the 100SURF porewater. The sequence of $\mathrm{O}_{2}$ penetration (Fig. 4) was inversely related to $\mathrm{O}_{2}$ fluxes: CTRL had the highest penetration $(5 \mathrm{~mm})$, then 30MIX $(4 \mathrm{~mm}), 100 \mathrm{MIX}(3.3 \mathrm{~mm})$ and 100SURF $(2 \mathrm{~mm})$.

\section{Nitrification and $\mathrm{NO}_{3}{ }^{-}$reduction}

Nitrification rates measured with the ${ }^{15} \mathrm{~N}$ isotope (Fig. 5A) were highest in 30MIX, followed by CTRL and 100MIX. No nitrification activity was detected in 100SURF. The isotopic measurements revealed that most of the $\mathrm{NO}_{3}^{-}$produced by nitrification was released to the water phase ( 88 to $91 \%$ ), while only a minor part was denitrified (Fig. 5A). Nitrification, measured with the acetylene inhibition method, gave rates close to the isotopic measurements (Fig. 5B). The measurements with the inhibition method in the CTRL sediment showed least variation, due to more stable $\mathrm{NH}_{4}{ }^{+}$fluxes from this compared to the loaded sediments. Nitrification measurements in the 100SURF were impossible due to variable $\mathrm{NH}_{4}{ }^{+}$effluxes in the individual cores. The variable $\mathrm{NH}_{4}{ }^{+}$fluxes indicated that the system was not in steady state. Denitrification rates (Fig. 5C) were low, less than $0.15 \mathrm{mmol} \mathrm{m}^{-2} \mathrm{~d}^{-1}$.
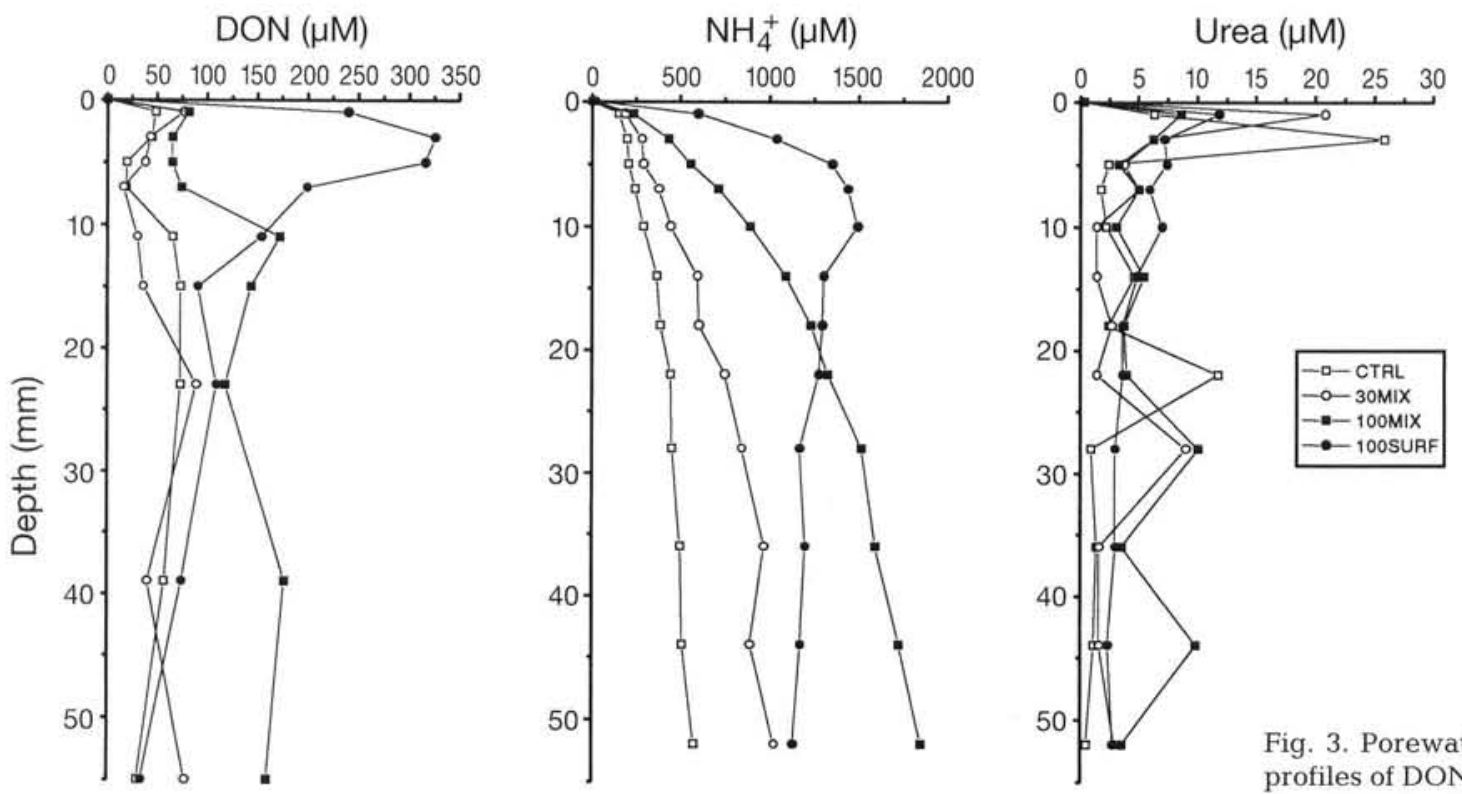

Fig. 3. Porewater concentration profiles of DON, $\mathrm{NH}_{4}{ }^{+}$, and urea 
Denitrification rates were correlated with nitrification rates. This resulted from the fact that water phase concentrations of $\mathrm{NO}_{3}{ }^{-}$were low (0 to $2.5 \mu \mathrm{M}$ ), so that denitrification was dependent on $\mathrm{NO}_{3}^{-}$produced by nitrification. During the incubation with $50 \mu \mathrm{M}^{15} \mathrm{NO}_{3}{ }^{-}$ in the water, the 100SURF showed a high potential for denitrification of water phase $\mathrm{NO}_{3}^{-}\left(2.44 \mathrm{mmol} \mathrm{m}{ }^{-2}\right.$ $\mathrm{d}^{-1}$ ), close to 5 times the potential in $100 \mathrm{MIX}$ at this high $\mathrm{NO}_{3}^{-}$concentration. Rates of dissimilatory reduction of $\mathrm{NO}_{3}{ }^{-}$to $\mathrm{NH}_{4}{ }^{+}$were estimated as ${ }^{15} \mathrm{NH}_{4}{ }^{+}$production from the ${ }^{15} \mathrm{NO}_{3}{ }^{-}$added to the inflow water. In all treatments the ${ }^{15} \mathrm{NH}_{4}{ }^{+}$production rates were below $1 \%$ of denitrification rates.

\section{Pools and fluxes of $\mathrm{N}$-species}

In order to estimate $\mathrm{N}$-balances in the different treatments, pools and fluxes of $\mathrm{N}$-species were compiled in Table 1 . The initial loading in the different treatments was calculated from the added amount of yeast cells using a C: $N$ ratio of 7.5 (Caffrey et al. 1993). The porewater pools were calculated from the measured concentrations in the upper $55 \mathrm{~mm}$, extrapolated to the total sediment depth of $170 \mathrm{~mm}$. KCl-extractable $\mathrm{NH}_{4}{ }^{+}$was included in these porewater pools (data not shown, average $K_{\text {ex }}=1.33$ adsorbed $\mathrm{NH}_{4}{ }^{+}$/interstitial $\mathrm{NH}_{4}{ }^{+}$, both calculated per sediment volume). The porewater concentrations were transformed to concentrations per sediment volume using a sediment porosity of

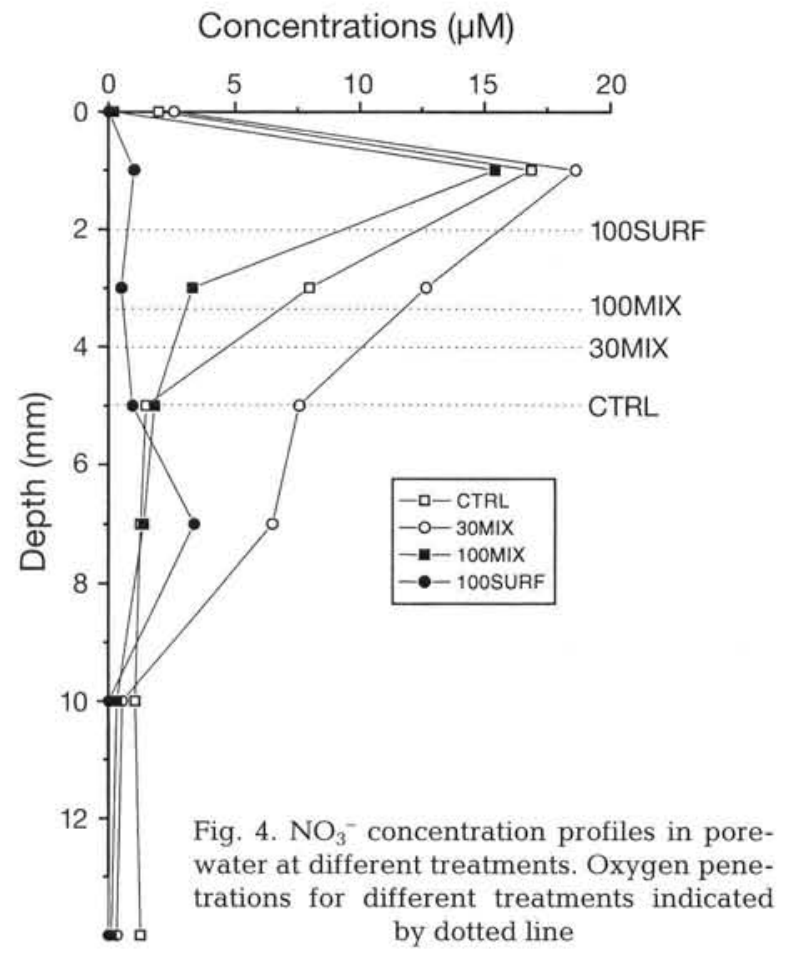

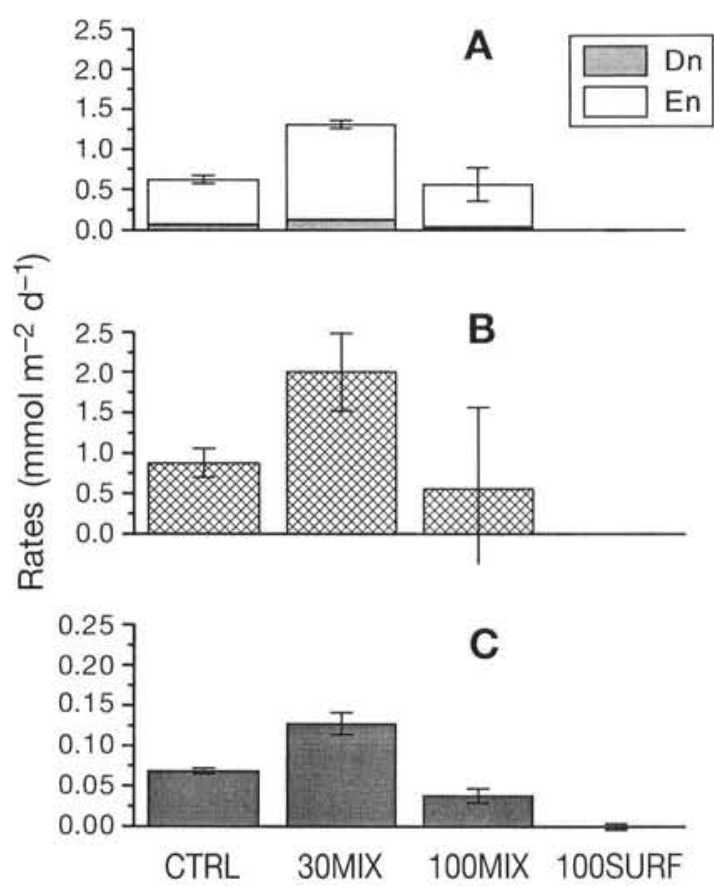

Fig. 5. (A) Nitrification measured with ${ }^{15} \mathrm{~N}$ isotopes, (B) nitrification measured with nitrification inhibition, and (C) denitrification measured with ${ }^{15} \mathrm{~N}$ isotopes. Rates from isotopic measurements calculated as the sum of denitrified $\mathrm{NO}_{3}{ }^{-}$from nitrification (Dn) and efflux of $\mathrm{NO}_{3}{ }^{-}$from nitrification in the sediment (En). Acetylene inhibition measurements in 100SURF not shown, due to large variation in $\mathrm{NH}_{4}{ }^{+}$effluxes. Averages of 4 cores shown; SE indicated by error bars

$35 \% \mathrm{v} / \mathrm{v}$, and related to loading as \% excess relative to CTRL. Total $\mathrm{N}$ fluxes were calculated by summing fluxes of the single species. In all treatments a considerable amount of the initial loading was in dissolved form in the porewater pool, predominantly as $\mathrm{NH}_{4}{ }^{+}$. The porewater pools relative to the initial loading (excess relative to CTRL) were highest in the mixed treatments ( 25 to $28 \%$ ), and only about half $(12 \%)$ in the 100SURF. The amount of the initial loading that left the sediment through efflux was $0.2 \% \mathrm{~d}^{-1}$ in the 30MIX, $0.5 \% \mathrm{~d}^{-1}$ in the $100 \mathrm{MIX}$, and $1.8 \% \mathrm{~d}^{-1}$ in the 100SURF treatment with a considerable time delay in all cores between loading and effluxes.

\section{DISCUSSION}

The response of nitrification to the different loadings was consistent between the $\mathrm{NO}_{3}{ }^{-}$effluxes and profiles, and the direct measurements with isotopes and acetylene inhibition. Nitrification was stimulated in 30MIX relative to CTRL. This response can be explained by increased $\mathrm{NH}_{4}{ }^{+}$availability in the organically loaded cores. Nitrification was smaller in 100MIX than CTRL or 30MIX, even though $\mathrm{NH}_{4}{ }^{+}$was abundant, as seen 
Table 1. Pools and fluxes of $\mathrm{N}$-species in the sediments with different organic loading. Porewater pools of dissolved $\mathrm{N}$ calculated by addition of measured concentrations of different $\mathrm{N}$-species, extrapolated to total sediment depth. Excess porewater pools calculated as excess relative to CTRL

\begin{tabular}{|c|c|c|c|c|c|c|c|c|c|}
\hline \multirow[t]{2}{*}{ Treatment } & \multicolumn{2}{|c|}{- Pools $\left(\mathrm{mmol} \mathrm{N} \mathrm{m}^{-2}\right)-$} & \multicolumn{6}{|c|}{$\longrightarrow$ Fluxes $\left(\mathrm{mmol} \mathrm{N} \mathrm{m}^{-2} \mathrm{~d}^{-1}\right)$} & \multirow{2}{*}{$\begin{array}{c}\mathrm{O}_{2} \text { uptake/ } \\
\mathrm{CO}_{2} \text { efflux } \\
\left(\mathrm{mmol} \mathrm{m}^{-2} \mathrm{~d}^{-1}\right)\end{array}$} \\
\hline & Loading & $\begin{array}{l}\text { Excess pore- } \\
\text { water pools } \\
\text { (\% of loading) }\end{array}$ & $\mathrm{NH}_{4}{ }^{+a}$ & $\mathrm{NO}_{3}^{-}$ & DON & Urea & $\mathrm{N}_{2}$ & $\begin{array}{l}\text { Total } \\
\text { efflux }\end{array}$ & \\
\hline CTRL & 0 & $0(0 \%)$ & 0.3 & 0.7 & 0.4 & 0 & 0.1 & 1.5 & $9.9 / 17.7$ \\
\hline 30MIX & 252 & $71(28 \%)$ & 0.7 & 0.9 & 0.2 & -0.1 & 0.1 & 1.8 & $8.7 / 21.4$ \\
\hline 100MIX & 840 & $208(25 \%)$ & 4.6 & 0.2 & 0.4 & -0.2 & 0 & 5.0 & $19.3 / 32.4$ \\
\hline 100SURF & 840 & $101(12 \%)$ & 12.6 & 0 & 3.8 & -0.1 & 0 & 16.3 & $62.5 / 64.4$ \\
\hline
\end{tabular}

from the concentration profiles and large effluxes. Since the $\mathrm{O}_{2}$ penetration depths were almost the same in 30MIX and 100MIX, the decrease in rates may have been due to partial inhibition of nitrification in 100MIX by e.g. $\mathrm{H}_{2} \mathrm{~S}$. Nitrification was completely absent in 100SURF, even though $\mathrm{O}_{2}$ penetration was $2 \mathrm{~mm}$ and $\mathrm{NH}_{4}{ }^{+}$very abundant. The nitrifying bacteria may have been killed by $\mathrm{H}_{2} \mathrm{~S}$ earlier in the incubation (Henriksen \& Kemp 1988).

In contrast to the earlier experiment by Caffrey et al. (1993), where there was high $\mathrm{NO}_{3}{ }^{-}$in the overlying water, denitrification rates were low, and insignificant in the total N-balance of any of the treatments (Table 1). This was evidently because low concentrations of $\mathrm{NO}_{3}$ were present in the overlying water in this experiment, so that denitrification depended solely on $\mathrm{NO}_{3}{ }^{-}$produced by nitrification. During the ${ }^{15} \mathrm{~N}$ measurements, however, where ${ }^{15} \mathrm{NO}_{3}{ }^{-}$was added to the water phase, the highest potential for denitrification of water phase $\mathrm{NO}_{3}{ }^{-}$occurred in 100SURF $\left(2.4 \mathrm{mmol} \mathrm{m}{ }^{-2} \mathrm{~d}^{-1}\right.$ with $50 \mu \mathrm{M} \mathrm{NO}_{3}{ }^{-}$in the overlying water), thus verifying the earlier results of Caffrey et al. (1993) with direct measurements. The finding that only a small part (10 to $18 \%$ ) of the $\mathrm{NO}_{3}$ - produced from nitrification was denitrified and that most was effluxed to the water phase had been expected. In a situation where $\mathrm{H}_{2} \mathrm{~S}$ is not free to diffuse, due to reaction with iron compounds, $\mathrm{NH}_{4}{ }^{+}$ from deeper layers in the sediment can diffuse up to the sediment surface. The absence of $\mathrm{H}_{2} \mathrm{~S}$ and of appreciable amounts of degradable carbon can result in deep penetration of oxygen, as observed in these data (Fig. 4). The presence of $\mathrm{NH}_{4}{ }^{+}$and $\mathrm{O}_{2}$ leads to active nitrification, but the low amount of organic matter restricts denitrification, resulting in an efflux of $\mathrm{NO}_{3}^{-}$(Blackburn \& Blackburn 1993).

In the mixed treatments and the CTRL cores, DON was predominantly degraded in the sediment, showing no accumulation in the deeper strata as was seen in the $\mathrm{NH}_{4}{ }^{+}$profiles. This is consistent with DON as an important intermediate in the mineralization of organic material, and $\mathrm{NH}_{4}{ }^{+}$as the final product. The decrease in DON concentrations in the top sediment layer indicated higher turnover rates in this layer, or that DON may have left the sediment by diffusion. Detailed modelling will be required to reveal the turnover time of the pools in the different depths.

Urea was present in the sediment porewater pools in concentrations up to $26 \mu \mathrm{M}$, but there was no efflux of urea. A calculation of the expected diffusion to the water phase from the CTRL sediment gives rates of $\sim 0.1 \mathrm{mmol} \mathrm{m}^{-2} \mathrm{~d}^{-1}$, which was at the limit of urea detection. The diffusion was calculated using Fick's 1st law: Flux $=\mathrm{d} C / \mathrm{d} x \times$ porosity ${ }^{2} \times D\left(D_{\text {urea }}=1.5 \times 10^{-5} \mathrm{~s}^{-1}\right.$, $\mathrm{d} C / \mathrm{d} x=26 \mu \mathrm{M} / 0.3 \mathrm{~cm}$, porosity $=0.35$ ). A finer resolution than $2 \mathrm{~mm}$ in the slicing of the top sediment layer could have revealed diffusion/reaction gradients better. The low effluxes seen here were contrary to several investigations in natural systems (Lomstein et al. 1989, Lomstein \& Blackburn 1992). The absence of macrofauna, removed by sieving, may have had some influence.

The calculation of the mass balances (Table 1) revealed that a relatively large amount of the initial loading was present in the porewater in dissolved or adsorbed forms, especially in the mixed treatments. The daily total effluxes in the mixed treatments showed that it would take 200 to $500 \mathrm{~d}$ to return to CTRL levels and $50 \mathrm{~d}$ in the 100SURF treatment, assuming that the rates measured here would be the same in the whole time period. This illustrates that when mineralization occurs at depth in the sediment, it will take a long time before these events are reflected in sediment-water exchange processes $\left(\mathrm{CO}_{2}, \mathrm{O}_{2}, \mathrm{NH}_{4}{ }^{+}\right.$, $\mathrm{NO}_{3}{ }^{-}, \mathrm{DON}$, urea).

Even at the higher loading rates an oxic zone was present at the time of measurement, yet nitrification and denitrification rates decreased. Nitrification in the 100 SURF was zero, in contrast to $100 \mathrm{MIX}$, and dissolved forms of $\mathrm{N}$ from mineralization processes returned to the water phase faster in the SURF treatment 
than in the MIX treatment, thus indicating the effect of physical mixing (e.g. bioturbation) on the rate at which regenerated $\mathrm{N}$ became available for new primary production.

With regard to eutrophication due to $\mathrm{N}$ loading of coastal areas, these data indicate that at higher loading rates the $\mathrm{N}$ removal by denitrification in the sediment decreases as predicted (Blackburn 1990). The mixing of organic matter into deep sediment layers resulted in a disassociation of the $\mathrm{C}$ and $\mathrm{N}$ cycles; the carbon was oxidized to $\mathrm{CO}_{2}$, but the $\mathrm{NH}_{4}{ }^{+}$was not oxidized until it reached the oxic sediment surface. The lack of competition for $\mathrm{O}_{2}$, due to the low concentration of organic matter, resulted in high nitrification rates, again predicted from modelling (Blackburn \& Blackburn 1993).

These experiments showed the responses of a highly simplified sediment system at a certain time after the addition of a labile and homogenous substrate. The time-succession of the bacterial processes, including population development, were not measured in detail, but could perhaps be modelled based on the present data. In natural systems, with bioturbation (Enoksson \& Samuelsson 1987, Kristensen 1988), anthropogenic influence, benthic micro- and macrophytes (Sundbäck et al. 1991) and structurally much more complex substrates for mineralization, the response to organic loading is obviously more complex. The organic substrate would be expected to be transformed in food chains in the sediment, or to be resuspended and partially degraded before being mineralized in the sediment (Floderus \& Håkanson 1989). The type of sediment may also influence the processes through adsorptive properties and different diffusive coefficients. These experiments showed, however, the importance of organic loading, and the distribution of organic matter, in determining the rate at which inorganic nitrogen reached the water column and the rates of nitrification and coupled denitrification.

Acknowledgements. Part of this work was financed by grants from the Centre for Strategic Environmental Research in Marine Areas, grants no. 4.15 and 4.28 and the Commission of European Communities' STEP programme under contract number STEP-CT 90-0080 (DSCN).

\section{LITERATURE CITED}

Blackburn, T. H. (1979). Method for measuring rates of $\mathrm{NH}_{4}{ }^{+}$ turnover in anoxic marine sediments, using a ${ }^{15} \mathrm{~N}_{-} \mathrm{NH}_{4}{ }^{+}$ dilution technique. Appl. environ. Microbiol. 37: 760-765

Blackburn, T. H. (1990). Denitrification model for marine sediment. In: Blackburn, T. H., Sørensen, J. (eds.) Denitrification in soil and sediment. Wiley, Chichester, p. 323-337

Blackburn, T. H., Blackburn, N. D. (1992). Model of nitrification and denitrification in marine sediments. FEMS Microbiol. Lett. 100: 517-522
Blackburn, T. H., Blackburn, N. D. (1993), Coupling of cycles and global significance of sediment diagenesis. Mar. Geol. 113: $101-110$

Bower, C. E., Holm-Hansen, T. (1980). A salicylate-hypochlorite method for determining ammonia in seawater. Can. J. Fish. Aquat. Sci. 37: 794-798

Caffrey, J. M., Sloth, N. P., Kaspar, H. F., Blackburn, T. H. (1993). Effect of organic loading on nitrification and denitrification in a marine sediment microcosm. FEMS Microbiol. Ecol. 12: 159-167

Enoksson, V., Samuelsson, M.-O. (1987). Nitrification and dissimilatory ammonium production and their effects on nitrogen flux over the sediment-water interface in bioturbated coastal sediments. Mar. Ecol. Prog. Ser. 36: 181-189

Fenchel, T., Blackburn, T. H. (1979). Bacteria and mineral cycling. Academic Press, New York

Floderus, S., Håkansson, L. (1989). Resuspension, ephemeral mud blankets and nitrogen cycling in Laholmsbukten, south east Kattegat. Hydrobiologia 176/177: 61-75

Grashoff, K., Ehrhardt, M., Kremling, K. (1983). Methods of seawater analysis, 2nd edn. Verlag Chemie, Weinheim

Henriksen, K., Kemp, W. M. (1988). Nitrification in estuarine and coastal marine sediments. In: Blackburn, T. H., Sørensen, J. (eds.) Nitrogen cycling in coastal marine environments. SCOPE, Wiley \& Sons, p. 207-249

Kelly, J. R., Berounsky, V. M., Nixon, S. W., Oviatt, C. A. (1985). Benthic pelagic coupling and nutrient cycling across an experimental eutrophication gradient. Mar. Ecol. Prog. Ser. 26: 207-219

Kelly, J. R., Nixon, S. W. (1984). Experimental studies of the effect of organic deposition on the metabolism of a coastal marine bottom community. Mar. Ecol. Prog. Ser. 17: $157-169$

Kemp, W. M., Boynton, W. R. (1984). Spatial and temporal coupling of nutrient inputs to estuarine primary production: the role of particulate transport and decomposition. Bull. mar. Sci. 35: 522-535

Kristensen, E. (1988). Benthic fauna and biogeochemical processes in marine sediments: microbial activities and fluxes. In: Blackburn, T. H., Sørensen, J. (eds.) Nitrogen cycling in coastal marine environments. SCOPE, Wiley \& Sons, p. 275-299

Lomstein, B., Blackburn, T. H. (1992). Sediment nitrogen cycling in Aarhus Bay, Denmark. Miljøministeriet, Copenhagen

Lomstein, B. A., Blackburn, T. H., Henriksen, K. (1989). Aspects of nitrogen and carbon cycling in the northern Bering Shelf sediment. I. The significance of urea turnover in the mineralization of $\mathrm{NH}_{4}{ }^{+}$. Mar. Ecol. Prog. Ser. 57: $237-247$

Nielsen, L. P. (1992). Denitrification in sediment determined from nitrogen isotope pairing. FEMS Microbiol. Ecol. 86: $357-362$

Nishio, T., Koike, I., Hattori, A. (1983). Estimates of denitrification and nitrification in coastal and estuarine sediments. Appl. environ. Microbiol. 45: 444-450

Price, N. M., Harrison, P. J. (1987). Comparison of methods for the analysis of dissolved urea in seawater. Mar. Biol. 94: $307-317$

Revsbech, N. P. (1989). An oxygen microsensor with a guard cathode. Limnol. Oceanogr. 34: 474-478

Risgaard-Petersen, N., Rysgaard, S., Revsbech, N. P. (1993). A sensitive assay for determination of ${ }^{14} \mathrm{~N} /{ }^{15} \mathrm{~N}$ isotope distribution in $\mathrm{NO}_{3}^{-}$, J. microbiol. Meth. 17: 155-164

Seitzinger, S. P. (1990). Denitrification in aquatic sediments. In: Revsbech, N. P., Sørensen, J. (eds.) Denitrification in soil and sediment. Plenum Press, New York, p. 301-322 
Sloth, N. P., Nielsen, L. P., Blackburn, T. H. (1992). Measurement of nitrification in intact sediment cores using acetylene inhibition. Limnol. Oceanogr. 37: 1108-1112

Strickland, J. D. H., Parsons, T. R. (1965). A practical handbook of sea water analysis. Bull. Fish. Res. Bd Can. 167

Sundbäck, K., Enoksson, V., Granéli, W., Pettersson, K. (1991). Influence of sublittoral microphytobenthos on the

This article was submitted to the editor oxygen and nutrient flux between sediment and water: a laboratory continuous-flow study. Mar. Ecol. Prog. Ser, 74: 263-279

Walsh, T. W. (1989). Total dissolved nitrogen in seawater: a new high-temperature combustion method and a comparison with photo-oxidation. Mar. Chem. 26: 295-311

Manuscript first received: May 30, 1994

Revised version accepted: August 16, 1994 